\title{
Effect of pH on Escherichia coli Removal by Electrocoagulation and Elimination Kinetics after Treatment
}

\author{
A. C. Ndjomgoue-Yossa $\mathbb{D}^{1,2}$ C. P. Nanseu-Njiki, ${ }^{2}$ and E. Ngameni ${ }^{2}$ \\ ${ }^{1}$ Department of Chemistry, Faculty of Sciences, The University of Bamenda, P.O Box 39, Bambili, Bamenda, Cameroon \\ ${ }^{2}$ Laboratoire de Chimie Analytique, Faculté des Sciences, Université de Yaoundé I, B P 812, Yaoundé, Cameroon \\ Correspondence should be addressed to A. C. Ndjomgoue-Yossa; yossa76@yahoo.fr
}

Received 23 August 2021; Revised 22 December 2021; Accepted 20 January 2022; Published 8 February 2022

Academic Editor: Mohamed Azaroual

Copyright (c) 2022 A. C. Ndjomgoue-Yossa et al. This is an open access article distributed under the Creative Commons Attribution License, which permits unrestricted use, distribution, and reproduction in any medium, provided the original work is properly cited.

\begin{abstract}
There are different techniques for removing microorganisms in wastewater, each with its own advantages and disadvantages. Electrocoagulation because of its simplicity has gained great attention and is used for the removal of various ions, organic matters, and microorganisms. In this study, the effectiveness and mechanism of Escherichia coli (E. coli) removal by electrocoagulation process using aluminum and ordinary steel electrodes at different initial-pH and the kinetics of elimination of $E$. coli in solution after treatment were investigated. Artificial wastewater contaminated by E. coli culture was used in the experiments. The results show that the initial-pH influences significantly the effectiveness of E. coli removal. Under the experimental conditions used, more than $5 \log$ removal of $E$. coli is obtained, irrespective of the nature of the electrode (ordinary steel or aluminum) and the value of the initial $\mathrm{pH}$. On the one hand, the best rates of elimination are obtained for solutions that are slightly acidic ( $\mathrm{pH} 5.5)$ and for an alkaline $\mathrm{pH}$ (8.5 and 10). On the other hand, the elimination decreases for a neutral solution and for a very acidic solution ( $\mathrm{pH} 2.9$ ) because of the strong resistance developed by $E$. coli at those $\mathrm{pH}$ values. For optimal treatment, the choice of electrode material depends on the initial $\mathrm{pH}$. Furthermore, the study of the kinetics of elimination of $E$. coli after treatment shows the remanent power of the electrocoagulation process. It allows reducing treatment time and energy consumption, thus reducing the cost of treatment.
\end{abstract}

\section{Introduction}

Waterborne diseases caused by bacterial contamination are a serious concern in the world health community. To address this issue, there is a continuous need to develop efficient and cost-effective disinfection technologies. Several disinfection technologies, such as ozonation, ultraviolet disinfection, and chlorination, are currently in use for water treatment. However, even though these technologies are effective, their utilization is limited by operational safety, the formation of unwanted by-products, and a high cost for operation and maintenance [1-4].

One of the emerging technologies that proved its efficiency against a broad spectrum of microorganisms is electrochemical disinfection. It has gained increasing attention as an alternative to the conventional methods of disinfection since it is environmentally friendly and is known to inactivate a wide variety of microorganisms, from bacteria to viruses and algae [3-10].

Recently, it has been demonstrated that electrocoagulation as an electrochemical disinfection technology offers an attractive alternative compared to conventional technologies for the treatment of microorganisms in water, with relatively low energy consumption $[6,7,10,11]$. Electrocoagulation has been combined with an ultrasonic source [12] and with electro-Fenton treatment [13] to improve the removal of bacteria, even if, like any other treatment method, the electrocoagulation technology still has some drawbacks that could limit its applications [14]. Among microorganisms, the removal of $E$. coli in water is of great interest because of its importance as an indicator of fecal pollution $[15,16]$. Moreover, 
E. coli is one of the bacteria generally responsible for intestinal infections [17].

The efficiency of electrocoagulation depends on various parameters, among which the initial-pH is known as one of the main factors that controls its performance since it plays an important role in the rate of metal hydroxides formation, and the majority of species in the solution are $\mathrm{pH}$-dependent [18]. Moreover, $\mathrm{pH}$ plays a crucial role in the removal of microorganisms in an aqueous solution. In fact, alkaline $\mathrm{pH}$ results in a significant decrease in the survival time of $E$. coli in wastewater $[19,20]$, and at low $\mathrm{pH}$ environments, E. coli develops tolerance to acidity [21]. In addition, most of the microorganisms grow better at $\mathrm{pH}$ values between 6.6 and $7.5[22,23]$.

To the best of our knowledge, very few studies investigated the $\mathrm{pH}$ effect on the removal of microorganisms while using the electrocoagulation process $[3,10]$, and the kinetics of elimination of microorganisms after treatment have never been investigated. Therefore, the main purpose of this study was the assessment of the $\mathrm{pH}$ effect on the removal of E. coli while using electrocoagulation and the investigation of the kinetics of elimination of $E$. coli in solution after treatment. Elsewhere, the mechanism involved during the treatment will be suggested.

\section{Material and Methods}

2.1. Experimental Apparatus. The experiments were conducted in an electrochemical cell under the conditions of a batch system. The electrocoagulation reactor consists of a $100 \mathrm{~cm}^{3}$ glass beaker mounted with two electrodes plate of $10 \mathrm{~cm} \times 2 \mathrm{~cm} \times 0.2 \mathrm{~cm}$ each. The electrodes were positioned vertically and parallel to each other, with an interelectrode distance of $1 \mathrm{~cm}$. The effective area of the electrode used during a given experiment depends on the electrocoagulation parameters. The electrode substrate material was aluminum and ordinary steel. Prior to each experiment, the electrodes were (1) sanded with a finely graded sandpaper to remove corrosion products from the electrode's surface. (2) The electrodes were washed with distilled water, (3) immersed in alcohol (90\%) to be sterilized, (4) rinsed with distilled water, and dried in the incubator at $110^{\circ} \mathrm{C}$. A magnetic stirrer (Stuart heat-stir SB 162) was used to homogenize the solution during the experiment. The current was provided by a laboratory DC power supply (ERMES M10-SP-303, $30 \mathrm{~V}-3 \mathrm{~A}$ ). After each treatment, conductivity and $\mathrm{pH}$ were determined using a multiparameter apparatus (Multi 340i/SET Weight Watchers International $\mathrm{pH}$-meter).

2.2. Treatment Procedures and Counting of E. coli. E. coli (strain ATCC 833), provided by Centre Pasteur of Yaounde-Cameroon, was used as an indicator bacterium in all experiments. The pure strain of E. coli as provided was used to prepare an artificial solution of $E$. coli at a concentration of $10^{8} \mathrm{UFC} / 100 \mathrm{~mL}$. For each group of experiments, $5 \mathrm{~cm}^{3}$ of this contaminated solution was diluted into deionized and sterilized water to give an initial cell density between $5 \times 10^{5} \mathrm{UFC} / 100 \mathrm{~mL}$ and $4 \times 10^{7} \mathrm{UFC} / 100 \mathrm{~mL}$. To increase the conductivity of the artificially polluted water, sodium nitrate $(1 \mathrm{~g} / \mathrm{L})\left(\mathrm{NaNO}_{3}, 99 \%\right.$ from Prolabo) was used as a supporting electrolyte.

To study the effect of the initial-pH, the charge loading ranging from 0 to $40 \mathrm{~F} / \mathrm{m} 3$ was applied while keeping the current density constant at $12.5 \mathrm{~mA} / \mathrm{cm} 2$. These experimental conditions are motivated by previous works, which have established that charge loading influenced significantly the inactivation efficiencies than current density $[7,24]$. The initial $\mathrm{pH}$ was adjusted with $0.1 \mathrm{M}$ nitric acid (HNO3, 96\% from Aldrich) and $0.1 \mathrm{M}$ sodium hydroxide $(\mathrm{NaOH}, 99.9 \%$ from Prolabo) solutions.

To study the elimination kinetics after treatment, a highly concentrated solution of E. coli $\left(4 \times 10^{7} \mathrm{CFU} / 100 \mathrm{~mL}\right)$ was treated, using four different charge loadings values $\left(1.24 \mathrm{~F} / \mathrm{m}^{3}, 3.73 \mathrm{~F} / \mathrm{m}^{3}, 6.21 \mathrm{~F} / \mathrm{m}^{3}\right.$, and $\left.12.43 \mathrm{~F} / \mathrm{m}^{3}\right)$, with a current density of $12.5 \mathrm{~mA} / \mathrm{cm}^{2}$, an initial $\mathrm{pH}$ of 7.02 , and the iron electrodes and $\mathrm{NaNO}_{3}(1 \mathrm{~g} / \mathrm{L})$ as supporting electrolytes. The treated solutions by electrocoagulation were analyzed just after the treatment and after $2 \mathrm{~h}, 6 \mathrm{~h}, 18 \mathrm{~h}$, and $24 \mathrm{~h}$.

For each treatment, $50 \mathrm{~cm}^{3}$ of the contaminated water was spiked in the electrocoagulation reactor, where either aluminum or ordinary steel electrode was used, and after the electrochemical process was conducted at room temperature $\left(\approx 22^{\circ} \mathrm{C}\right)$, an aliquot sample was collected and filtered using the Whatman filter paper no. $40(2.5 \mu \mathrm{m})$ before counting the residual E. coli.

The concentration of $E$. coli was determined using the membrane filtration method with appropriate culture media [Lactose TTC (2, 3, 5-triphenyltetrazolium chloride) agar with tergitol 7 base]. An incubation time of $24-48 \mathrm{~h}$ at $44^{\circ} \mathrm{C}$ allowed the colonies to grow [25]. All experiments were performed in triplicate for statistical analyses, which were conducted using Microsoft Excel 2013. The inactivation efficiency of $E$. coli was determined for each treatment taking into account the number of $E$. coli in the solution and expressed as log units.

\section{Results and Discussion}

3.1. Effect of Initial $p H$ on E. coli Removal by Electrocoagulation. To illustrate the effect of $\mathrm{pH}$ on $E$. coli removal by electrocoagulation using ordinary steel and aluminum electrodes, experiments were performed at different initial $\mathrm{pH}$ values $(2.9,5.5,7.1,8.5$, and 10.0). For each $\mathrm{pH}$ value, the charge loading was varied from 0 to $37.3 \mathrm{~F} / \mathrm{m} 3$.

Figure 1 depicts the effect of charge loading on E. coli inactivation using ordinary steel electrodes.

It appears that $E$. coli elimination rates increase significantly with the charge loading at any initial-pH value. The $\log (\mathrm{CFU} / 100 \mathrm{~mL})$ decreases strongly with the charge loading. However, it can be noticed that there is a considerable difference between the curves. For a charge density of $6.21 \mathrm{~F} / \mathrm{m} 3$, the removal rates are $2.36 \mathrm{log}, 3.33 \mathrm{log}, 4.31 \mathrm{log}, 4$ $\log$, and $6.14 \log$ for the initial $\mathrm{pH}$ values of $2.92,7.1,8.5,10$, and 5.5, respectively. The elimination rates increase with $\mathrm{pH}$ from 2.92 to 5.5 and then decrease around the neutral $\mathrm{pH}$ 


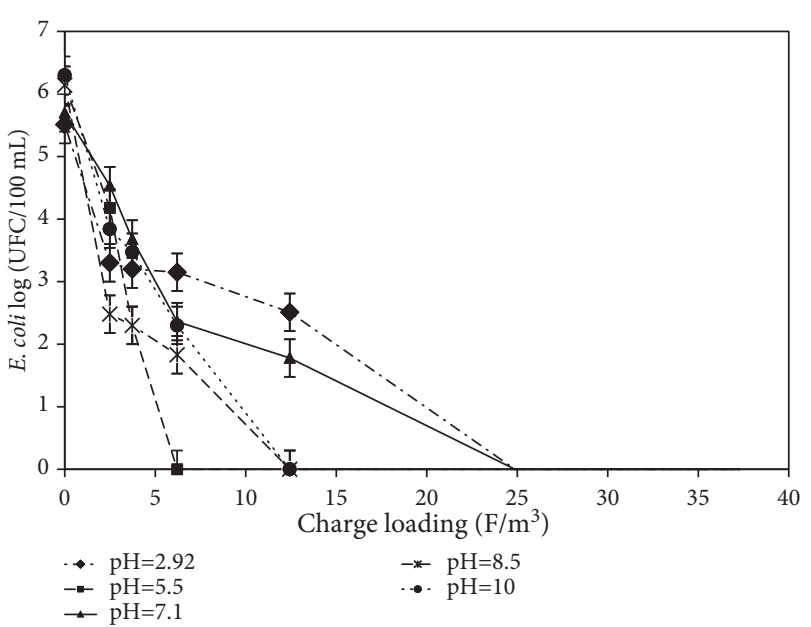

FIGURE 1: Effect of charge loading and initial $\mathrm{pH}$ on inactivation of E. coli: current density: $12.5 \mathrm{~mA} / \mathrm{cm}^{2}$, supporting electrolyte: NaNO3 $1 \mathrm{~g} / \mathrm{L}$, and ordinary steel electrode.

and finally increase with a subsequent $\mathrm{pH}$ raise. Elsewhere, the total removal of $E$. coli is obtained for the charge loading of $6.21 \mathrm{~F} / \mathrm{m} 3$ at $\mathrm{pH} 5.5,12.43 \mathrm{~F} / \mathrm{m} 3$ at $\mathrm{pH} 8.5$ and 10 , and $24.87 \mathrm{~F} / \mathrm{m} 3$ at $\mathrm{pH} 2.92$ and 7.1 . The change in initial $\mathrm{pH}$, therefore, has a significant effect on the removal efficiency of E. coli using the ordinary steel electrodes. The best removal rates are obtained at $\mathrm{pH}$ 5.5. Similar results were obtained by Aronsson et al. following the exposure of $E$. coli to an electric field and varying the $\mathrm{pH}$ of the medium [26], as well as by Lynn et al. while using electrocoagulation as a pretreatment for the electrooxidation of E. coli [3].

From the analysis of the curves in Figure 2, it appears that the elimination rates of $E$. coli increase strongly with the charge loading, irrespective of the initial $\mathrm{pH}$ while using aluminum as electrode material. The curves decrease strongly with the charge loading, irrespective of the initial $\mathrm{pH}$. They are similar for the initial $\mathrm{pH}$ of 5.5 and 10 , whereas there is a considerable difference between the other curves. For example, for a charge loading of $6.21 \mathrm{~F} / \mathrm{m} 3$, there is a reduction in the bacterial load of $1.92 \mathrm{log}, 2.7 \mathrm{log}, 4.2 \mathrm{log}, 6.3 \mathrm{log}$, and $6.3 \mathrm{log}$, respectively, at the initial $\mathrm{pH}$ of $7.1,2.92,8.5,10$, and 5.5. The bacterial load reduction increases from 2.9 to 5.5 , reaching a maximum, and then, it decreases from 5.5 to 7.1 , and it increases thereafter for alkaline $\mathrm{pH}$. The total elimination of $E$. coli in solution is obtained for a charge loading of $6.21 \mathrm{~F} / \mathrm{m} 3$ for $\mathrm{pH} 5.5$ and $\mathrm{pH} 10,12.43 \mathrm{~F} / \mathrm{m} 3$ for $\mathrm{pH} 8.5$, $24.87 \mathrm{~F} / \mathrm{m} 3$ for $\mathrm{pH} 2.9$, and finally, $37.30 \mathrm{~F} / \mathrm{m} 3$ for $\mathrm{pH} 7.1$ (Figure 2).

From this result, it appears that the initial $\mathrm{pH}$ has a significant effect on the removal efficiency of microorganisms in solution by electrocoagulation with aluminum electrodes. The best removal rates are obtained at $\mathrm{pH} 5.5$ and 10.

On the aluminum electrode, the difference between the elimination rates of $E$. coli in water following the initial $\mathrm{pH}$ can be explained by the fact that the main chemical reactions during electrocoagulation are as follows:

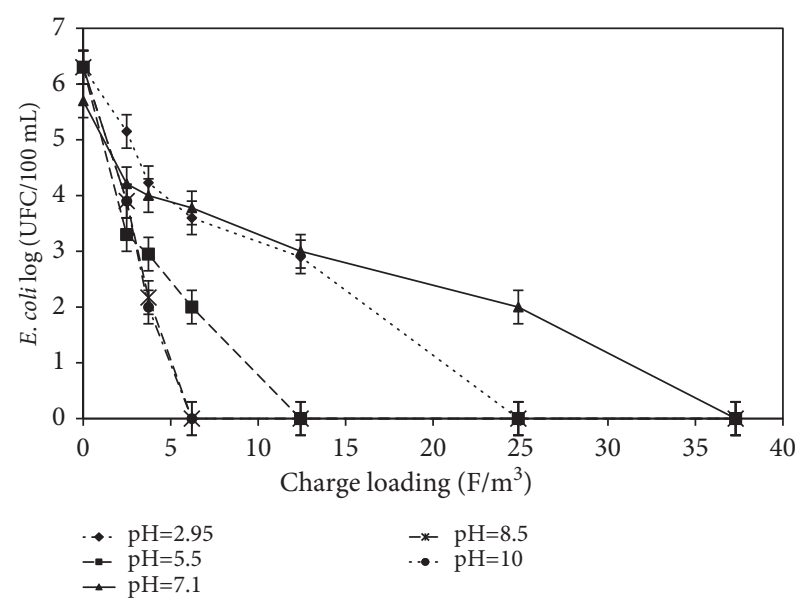

FIgURE 2: Effect of charge loading and initial $\mathrm{pH}$ on inactivation of E. coli: current density: $12.5 \mathrm{~mA} / \mathrm{cm}^{2}$, supporting electrolyte: NaNO3 $1 \mathrm{~g} / \mathrm{L}$, and aluminum electrode.

anode: $\mathrm{Al} \longrightarrow \mathrm{Al}^{3+}+3 e^{-}$
cathode: $2 \mathrm{H}_{2} \mathrm{O}+2 e^{-} \longrightarrow \mathrm{H}_{2}+2 \mathrm{OH}^{-}$

Depending on the concentration of $\mathrm{Al}^{3+}$ electrogenerated and the initial $\mathrm{pH}$ range of the solution, different species of aluminum (monomers and polymers) can be formed in the solution.

The dependence of the elimination rate on the initial $\mathrm{pH}$ using ordinary steel and aluminum electrodes can be explained by the following facts:

(i) For a low initial $\mathrm{pH}$ of about 2 to 4, the hydroxide ions generated at the cathode can be neutralized by the hydronium ions present in the solution [27], thus limiting the formation of the metal complexes responsible for the neutralization of the bacterial charge and their elimination. Indeed, in the case of ordinary steel, the equation of the reaction likely to be realized in the very acidic medium is given by,

$$
2 \mathrm{Fe}+6 \mathrm{H}_{2} \mathrm{O} \longrightarrow \mathrm{O}_{2}+4 \mathrm{H}_{2}+2 \mathrm{Fe}(\mathrm{OH})_{2} \text {. }
$$

Although the oxygen produced is likely to form disinfectants in solution, it does not compensate for the absence of $\mathrm{Fe}(\mathrm{OH})_{3}$ precipitates, which are more adsorbent than $\mathrm{Fe}(\mathrm{OH})_{2}$ precipitates [10].

In the case of aluminum electrodes, monomeric cationic species, such as $\mathrm{Al}_{3+}, \mathrm{Al}(\mathrm{OH})^{2+}$, and $\mathrm{Al}(\mathrm{OH})_{2+}$, are predominant $[28,29]$. These are very poorly adsorbent compared to neutral $\mathrm{Al}(\mathrm{OH})_{3}$ species and polymeric species [30].

Moreover, E. coli can survive and resist in a very acidic medium $(\mathrm{pH}<4)$, developing a tolerance to acidity. In these extreme physical conditions, strong acids dissociate at the outer membrane of E. coli, however, they are unable to penetrate the cell membrane [31]. To counteract this adverse effect, E. coli synthesizes enzymes like carboxylases that neutralize excess protons [21]. To adapt and tolerate 
low $\mathrm{pH}$ environments, bacterial cells tend to change the value of their external $\mathrm{pH}$. Brown and Booth have demonstrated in 1991 that E. coli secreted carboxylase enzymes preferentially at very acidic $\mathrm{pH}$ [32]. The role of such enzymes is to increase the value of the external $\mathrm{pH}$, inducing thus acid tolerance in certain situations [33]. E. coli has several acid resistance systems that can be classified into 2 categories, depending on whether the system can be induced and functions in minimal medium without acid-tolerance responses (ATR) or requires some supplement forms (acid-resistance [AR] mechanisms) [21].

All these effects justify the low elimination rates observed at $\mathrm{pH}$ 2.92. Similar results were obtained by Gernaout et al. in 2008 during the electrocoagulation treatment of surface water containing E. coli. They found that the elimination rates were lower in a very acidic medium [10].

Moreover, inactivation efficiencies are almost similar with ordinary steel and with aluminum as electrode material using an initial $\mathrm{pH}$ between 2 and 4. It can be explained by the fact that, on the one hand, whatever the type of electrode material used, the metal hydroxides responsible for the neutralization of the bacterial charge and their elimination are weakly produced, and on the other hand, E. coli can survive and resist in a very acidic medium.

(ii) At $\mathrm{pH} 5.5$, the removal efficiency of E. coli in solution is higher, following the combination of several effects: most parts of the hydroxide complexes responsible for coagulation and precipitation of pollutants in solution are formed in the $\mathrm{pH}$ range between 5 and 9. It is the optimum $\mathrm{pH}$ range for performing electrocoagulation $[27,28]$. The adhesion of those precipitates to the cell walls results in bacteria encapsulation in flocs because of the interactions between electrocoagulation precipitates and phosphate functional groups on bacteria surfaces [34].

In the case of aluminum electrodes, the consecutive reactions that occur on the surface of the electrodes and in the solution can lead to the formation of monomeric hydroxides, such as $\mathrm{Al}(\mathrm{OH})_{2+}, \mathrm{Al}(\mathrm{OH})^{2+}$, $\mathrm{Al}(\mathrm{OH})_{3}$, and $\mathrm{Al}(\mathrm{OH})_{4}{ }^{-}$, and polymeric species, such as $\mathrm{Al}_{6}(\mathrm{OH})_{15^{3+}}, \mathrm{Al}(\mathrm{OH})_{17^{4+}}, \quad \mathrm{Al}_{8}(\mathrm{OH})_{20^{4+}}$, $\mathrm{Al}_{13} \mathrm{O}_{4}(\mathrm{OH})_{24^{7+}}$, and $\mathrm{Al}_{13}(\mathrm{OH})_{34^{5+}}$ [28-30]. All these oligometric species are finally transformed into a water-insoluble amorphous compound, $\mathrm{Al}(\mathrm{OH})_{3(\mathrm{~S})}$, via complex polymerization/precipitation kinetics. The chemical species responsible for the effectiveness of electrocoagulation in the $\mathrm{pH}$ range of 5 to 9 are the hydroxoaluminum polymer ions and the $\mathrm{Al}(\mathrm{OH})_{3}$ aluminum hydroxide precipitate. These two coagulating agents have a complementary action. Polymeric cations can adsorb to the negative charges of E. coli, thereby promoting aggregation by charge neutralization and/or bridging for flocculation.

Moreover, at low acidic $\mathrm{pH}$, the undissociated weak acids can diffuse freely through the cytoplasmic membrane. Once inside the cytoplasm, they dissociate and increase the internal $\mathrm{pH}$ of $E$. coli $[21,35]$. The ability to maintain the $\mathrm{pH}$ inside the cell close to neutrality ( $\mathrm{pH}$ homeostasis) is then disrupted, leading to the death of the cell. In addition, the membrane permeability increases because of the formation of pores in the cell wall (during the passage of electric current), and the $\mathrm{H}+$ transport rate also increases because of the osmotic imbalance around the cell [36]. It results in a reduction in cytoplasmic $\mathrm{pH}$ because a higher number of protons is available compared to a neutral $\mathrm{pH}$. The change in $\mathrm{pH}$ in the cell may induce chemical changes in the basic compounds, such as DNA or adenosine triphosphate, as explained by Wiggins [37]. In addition, oxidation and reduction reactions may occur within the cell structure [38]. All these effects are bactericidal, and the high inactivation efficiency of E. coli observed at pH 5.5 is mainly attributed to them. Lynn et al., using electrocoagulation as a pretreatment for the electrooxidation of $E$. coli, also found that lower initial $\mathrm{pH}$ (pH 5-6) improved E. coli mitigation during electrocoagulation [3].

Inactivation efficiencies at this $\mathrm{pH}$ are similar upon using ordinary steel or aluminum as an electrode material because the high elimination rate observed at a weakly acidic $\mathrm{pH}$ is mainly attributed to the free diffusion of chemical species using the cell wall, which causes a malfunction and destroys the bacterial cell [36].

(iii) At $\mathrm{pH} 7.1$, the efficiency of E. coli elimination decreases, although within the optimal $\mathrm{pH}$ range of electrocoagulation [28]. This decrease can be attributed to the fact that this $\mathrm{pH}$ is also in the optimal $\mathrm{pH}$ range of E. coli development [39]. Indeed, most microorganisms grow best at $\mathrm{pH}$ values between 6.6 and $7.5[22,23]$. When microorganisms grow outside their optimal $\mathrm{pH}$ range, it results in increased latency [40]. The role of $\mathrm{pH}$ in the survival of microorganisms is related to the ability of organisms to maintain the cytoplasmic $\mathrm{pH}$ near neutrality. To adapt and tolerate $\mathrm{pH}$ environments different from their optimum $\mathrm{pH}$ range, bacterial cells attempt to change the value of their external $\mathrm{pH}$ by engaging in complex physiological and genetic mechanisms [21]. In the case of $\mathrm{pH} 7.1$, the cells do not need any particular arrangement, and therefore, they are more resistant to environmental conditions. It leads to a decrease in the effectiveness of the treatment. Delaire et al., using Fe electrocoagulation to attenuate $E$. coli in synthetic Bengal 
groundwater, also found that $E$. coli reduction was significantly enhanced at lower initial $\mathrm{pH}$ compared to neutral $\mathrm{pH}$ [41].

Furthermore, as Ndjomgoue-Yossa et al. recently demonstrated during the treatment of water containing $E$. coli by electrocoagulation, inactivation efficiency is higher with ordinary steel as electrode material than with aluminum using an initial-pH 7.1 , because of the fact that iron hydroxides $\mathrm{Fe}(\mathrm{OH})_{3}$ lead to higher enmeshment and adsorption than aluminum hydroxides $\mathrm{Al}(\mathrm{OH})_{3}$ [7].

(iv) At alkaline $\mathrm{pH}$ (8.5 and 10), the elimination of E. coli in solution increases because the kinetics of production of the metal hydroxides responsible for the coagulation and the adsorption of the pollutants in the solution is high [28].

In the case of aluminum electrodes, the concentration of the monomeric anionic species $\mathrm{Al}(\mathrm{OH})_{4}$ - increases at the expense of the $\mathrm{Al}(\mathrm{OH})_{3(\mathrm{~S})}$ formation [28]. Moreover, the cathode could be chemically attacked by the $\mathrm{OH}^{-}$ions generated at the same time as the hydrogen gas $\mathrm{H}_{2}$ at high $\mathrm{pH}$ values [42] according to the following equation:

$$
2 \mathrm{Al}+6 \mathrm{H}_{2} \mathrm{O}+2 \mathrm{OH}^{-} \longrightarrow 2 \mathrm{Al}(\mathrm{OH})_{4^{-}}+3 \mathrm{H}_{2} \text {. }
$$

These aluminum complexes, $\left(\mathrm{Al}(\mathrm{OH})_{4}-\right)$, polymerize to form microsuspensions, and by the agglomeration of destabilized colloids, they turn into microflocs and then into larger flocs. These flocs are thus formed at the origin of the coagulation and precipitation of pollutants in the solution [43].

In addition, the alkaline $\mathrm{pH}$ has a harmful effect on E. coli. Mezrioui and Baleux showed in 1992 that the survival time of E. coli in wastewater purified by lagooning and protected from all solar radiation is much shorter in an alkaline medium in comparison with acidic and neutral environments [19]. This bactericidal effect of the alkaline $\mathrm{pH}$ can be attributed to the fact that the internal $\mathrm{pH}$ of $E$. coli is around neutrality, [44] and unlike the highly acidic environments where the bacterium adapts, the ability to maintain this internal $\mathrm{pH}$ of the cell near neutrality is low when the external medium is alkaline. It inflicts stress on the body, which can lead to the death of the cell. The devastating damage of a strong base also occurs because phospholipids, which form the cell membrane and the nucleic membrane, are broken down by hydroxyl ions. Base hydrolysis causes the saponification reaction of lipids, leading to the breakdown and lysis of membrane structure [35]. All this justifies the increased effectiveness of the treatment observed in an alkaline medium. Similar results were obtained by Gernaout et al. in 2008, who found that the efficiency of the elimination of $E$. coli by electrocoagulation using iron electrodes is high in an alkaline medium [10].

Moreover, the effectiveness of the treatment is higher with aluminum as electrode material than with ordinary steel in alkaline $\mathrm{pH}$ because of the high production of aluminum complexes $\mathrm{Al}(\mathrm{OH})_{4}{ }^{-}$in the solution following the simultaneous degradation of the aluminum anode and cathode at alkaline $\mathrm{pH}$, which is not the case for iron electrodes.

\subsection{Elimination Kinetics of $E$. coli after Treatment.} Electrocoagulation is a very efficient process for the removal of E. coli from water, which can be optimized by changing the electrical and physicochemical parameters, such as charge density, current density, electrode material, supporting electrolyte, initial $\mathrm{pH}$, and others. [3, 7-10]. In most cases, it takes quite a long treatment time to achieve the total removal of $E$. coli from water, which results in greater energy consumption, and therefore, a high cost of treatment.

To reduce treatment time for total removal, the elimination kinetics of $E$. coli after electrocoagulation treatment have been investigated. In fact, the idea of this study comes from the fact that the analyses carried out a few days after the treatment on solutions, which still contained E. coli even at very high concentrations after treatment, showed that $E$. coli were completely inactivated.

To study the elimination kinetics of $E$. coli after electrocoagulation treatment, four different charge loadings values $\left(1.24 \mathrm{~F} / \mathrm{m}^{3}, 3.73 \mathrm{~F} / \mathrm{m}^{3}, 6.21 \mathrm{~F} / \mathrm{m}^{3}\right.$, and $12.43 \mathrm{~F} /$ $\mathrm{m}^{3}$ ) have been used. The results obtained are shown in Figure 3.

As seen in Figure 3, it appears that the concentration of $E$. coli in solution continues to decrease after treatment. The kinetics of elimination increase with the charge loading used. A $1.5 \log , 1.9 \log , 2 \mathrm{log}$, and $2.2 \mathrm{log}$ reductions in E. coli were observed for a charge loading of $1.24 \mathrm{~F} / \mathrm{m}^{2}, 3.73 \mathrm{~F} / \mathrm{m}^{2}$, $6.21 \mathrm{~F} / \mathrm{m}^{2}$, and $12.43 \mathrm{~F} / \mathrm{m}^{2}$, respectively, $2 \mathrm{~h}$ after the treatment. Total inactivation was achieved after $6 \mathrm{~h}, 18 \mathrm{~h}$, and $24 \mathrm{~h}$ for a charge loading of $12.43 \mathrm{~F} / \mathrm{m}^{3}, 6.21 \mathrm{~F} / \mathrm{m}^{3}$, and $3.73 \mathrm{~F} / \mathrm{m}^{3}$, respectively. This result clearly shows that $E$. coli continue to be destroyed after treatment. It can be explained by two combined effects, which are as follows:

(1) The action of oxidants produced in situ during electrolysis [7]: those strong oxidants may continue to react with the material of the cell wall by oxidizing, for example, the $\mathrm{N}$-terminal amino groups of the membrane proteins. It weakens the resistance of the cells, thus causing massive lyses of the cells, which can lead to the death of the bacteria. The action of those oxidants was confirmed using sodium chloride as a supporting electrolyte. In fact, the analysis of the solution immediately after treatment with a charge loading of $6.21 \mathrm{~F} / \mathrm{m}^{3}$ gave a concentration of $6 \times 10^{2} \mathrm{CFU} / 100 \mathrm{~mL}$, and the total removal of $E$. coli was achieved after $5 \mathrm{~h}$. This rapid inactivation of $E$. coli in the solution containing chloride ions is because of the formation in the treated solution of active chlorine species (such as $\mathrm{ClO}^{-}$and $\mathrm{ClO}_{2}$ ) electrogenerated during the treatment $[5,7,45]$. It accelerates the inactivation of bacteria after treatment. In addition, the reactive iron species formed during electrocoagulation [46] capable of inactivating $E$. coli and viruses $[41,47]$ can continue to inactivate them after treatment. 


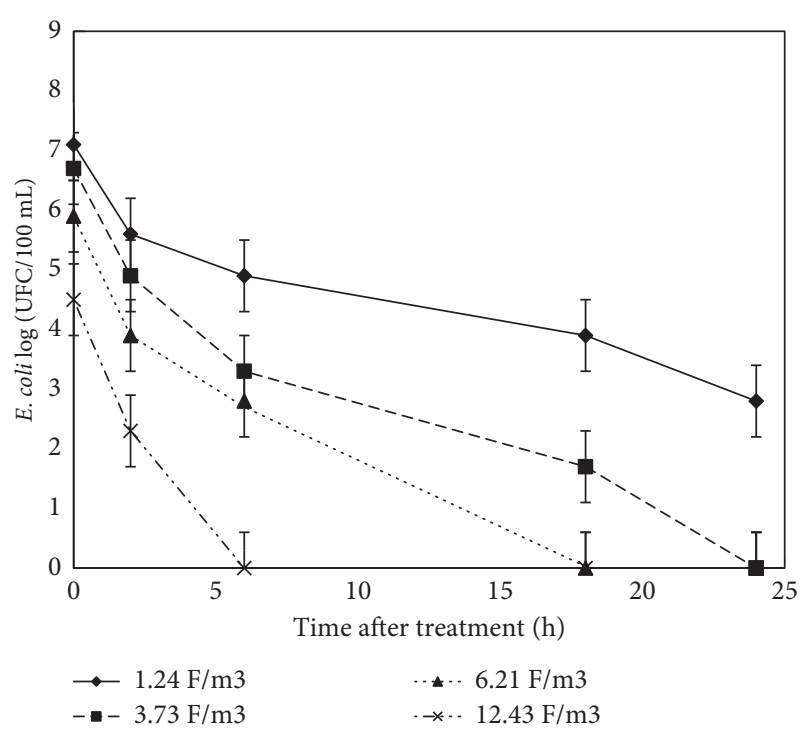

Figure 3: Elimination kinetics after treatment.

(2) The diffusion of chemical species through pores formed in the cell wall of E. coli during the passage of electric current [48] leads to their inactivation. Indeed, the electric field causes the permeability of the cell membrane of bacteria. These injured cells, which can, however, be regenerated in a favorable environment [49], are inactivated following the infiltration into the cytoplasm of chemicals. It causes dysfunction in the internal enzyme groups, and thus, it destroys the cells.

To these two effects, we can add the gradual death of bacteria that have been weakened or strongly stressed during the treatment. Cells with damaged cytoplasmic membranes have been shown to be inhibited by certain values of $\mathrm{pH}$ and/or salt concentration, which would normally allow growth [49].

The study of the elimination kinetics of E. coli after treatment by electrocoagulation shows the ability of this disinfection technique to maintain a residual concentration of disinfecting agents (its remanent power) after treatment, which is one of the fundamental characteristics sought for purification and production systems for drinking water. This study also makes it possible to consider the reduction of the application time of electrocoagulation for the total elimination of bacteria, which, in fact, allows reducing the treatment time and energy consumption, thus reducing the cost of treatment. Although it should be noted that at the end of the treatment, it still takes a certain time before obtaining the total removal. In other words, it saves processing costs while wasting a little more time.

\section{Conclusion}

The effects of initial $\mathrm{pH}$ on the removal of E. coli in artificial wastewater by electrocoagulation with ordinary steel and aluminum electrodes and elimination kinetics after treatment are systematically investigated, and the conclusions drawn are as follows: (i) The initial $\mathrm{pH}$ significantly affects the treatment efficiency, irrespective of the nature of the electrode used (ordinary steel or aluminum). For an optimal treatment, the choice of electrode material depends on the initial $\mathrm{pH}$. The best removal rates are obtained for weakly acidic solutions and for alkaline $\mathrm{pH}$. However, the elimination rate decreases for neutral and very acidic solutions.

(ii) From the results obtained, the removal of E. coli could be attributed to the three following reasons: the free diffusion through the cytoplasmic membrane of the chemical species, the harmful effect of the alkaline $\mathrm{pH}$ on $E$. coli, and adsorption by the metallic hydroxides formed in the solution.

(iii) The study of the kinetics of elimination of E. coli after treatment shows the remanent capacity of the electrocoagulation process. It could reduce treatment time and energy consumption, thus reducing the cost of treatment.

\section{Data Availability}

The data used to support the findings of this study are included within the article.

\section{Conflicts of Interest}

The authors declare that they have no conflicts of interest.

\section{Acknowledgments}

The authors wish to thank the International Foundation of Science (IFS) and the Organization for Prohibition of Chemical Weapons (OPCW) (project no. W/4395-1, Prof. Nanseu- Njiki C. P.) for their financial support. They also thank ISP for the grant offered to the African Network of Electroanalytical Chemists (ANEC).

\section{References}

[1] F. Abu-Shkara, I. Neeman, R. Sheinman, and R. Armon, "The effect of fatty acid alteration in coliform bacteria on disinfection resistance and/or adaptation," Water Science and Technology, vol. 38, no. 12, pp. 133-139, 1998.

[2] R. Sadiq and M. J. Rodriguez, "Disinfection by-products (DBPs) in drinking water and predictive models for their occurrence: a review," The Science of the Total Environment, vol. 321, no. 1, pp. 21-46, 2004.

[3] W. Lynn, J. Heffron, and B. K. Mayer, "Electrocoagulation as a pretreatment for electroxidation of E. coli," Water, vol. 11, no. 12, p. 2509, 2019.

[4] J. Isidro, D. Brackemeyer, C. Sáez et al., "How to avoid the formation of hazardous chlorates and perchlorates during electro-disinfection with diamond anodes?" Journal of Environmental Management, vol. 265, 2020.

[5] S. Gao, M. Du, J. Tian et al., "Effects of chloride ions on electro-coagulation-flotation process with aluminum electrodes for algae removal," Journal of Hazardous Materials, vol. 182, no. 1-3, pp. 827-834, 2010.

[6] S. Cotillas, J. Llanos, P. Cañizares, S. Mateo, and M. A. Rodrigo, "Optimization of an integrated 
electrodisinfection/electrocoagulation process with Al bipolar electrodes for urban wastewater reclamation," Water Research, vol. 47, no. 5, pp. 1741-1750, 2013.

[7] A. C. Ndjomgoue-Yossa, C. P. Nanseu-Njiki, I. M. Kengne, and E. Ngameni, "Effect of electrode material and supporting electrolyte on the treatment of water containing Escherichia coli by electrocoagulation," International Journal of Environmental Science and Technology, vol. 12, no. 6, pp. 2103-2110, 2014

[8] J. Wen, X. Tan, Y. Hu, Q. Guo, and X. Hong, "Filtration and electrochemical disinfection performance of PAN/PANI/ AgNWs-CC composite nanofiber membrane," Environmental Science \& Technology, vol. 51, no. 11, pp. 6395-6403, 2017.

[9] E. Huang, T. White, B. Wang, H. Shi, and J. Liu, "Disinfection of Escherichia coli by a reactive electrochemical membrane system involving activated carbon fiber cloth (ACFC)," Water, vol. 11, no. 3, p. 430, 2019.

[10] D. Ghernaout, A. Badis, A. Kellil, and B. Ghernaout, “Application of electrocoagulation in Escherichia coli culture and two surface waters," Desalination, vol. 219, no. 1-3, pp. 118-125, 2008.

[11] K. S. Hashim, P. Kot, S. Zubaid et al., "Energy efficient electrocoagulation using baffle-plates electrodes for efficient Escherichia Coli removal from wastewater," Journal of Water Process Engineering, vol. 33, 2019 ISSN 2214-7144.

[12] K. S. Hashim, S. S. M. Ali, J. K. AlRifaie et al., "Escherichia coli inactivation using a hybrid ultrasonic-electrocoagulation reactor," Chemosphere, vol. 247, Article ID 125868, 2020.

[13] E. Anfruns-Estrada, C. Bruguera-Casamada, H. Salvadó, E. Brillas, I. Sirés, and R. M. Araujo, "Inactivation of microbiota from urban wastewater by single and sequential electrocoagulation and electro-fenton treatments," Water Research, vol. 126, no. 1, pp. 450-459, 2017.

[14] K. S. Hashim, R. AlKhaddar, A. Shaw et al., "Electrocoagulation as an eco-friendly river water treatment method," in Advances in Water Resources Engineering and Management, vol. 39, Berlin, Germany, Springer, 2019.

[15] M. A. Hamouda, W. B. Anderson, M. I. Van Dyke, I. P. Douglas, S. D. McFadyen, and P. M. Huck, "Scenariobased quantitative microbial risk assessment to evaluate the robustness of a drinking water treatment plant," Water Quality Research Journal, vol. 51, no. 2, pp. 81-96, 2016.

[16] G. S. Fout, M. A. Borchardt, B. A. Kieke Jr., and M. R. Karim, "Human virus and microbial indicator occurrence in publicsupply groundwater systems: meta-analysis of 12 international studies," Hydrogeology Journal, vol. 25, no. 4, pp. 903-919, 2017.

[17] A. Chakraborty, A. Chandran, and K. B. Gopalkrishna, "Does citrus fruit juice have antibacterial effect against enteric pathogenic bacteria?" Indian Journal of Applied Research, vol. 5, no. 5, pp. 19-21, 2015.

[18] H. A. Salman and H. A. Wail, "Electrocoagulation technique used to treat wastewater: a review," American Journal of Engineering Research, vol. 7, no. 10, pp. 74-88, 2018.

[19] N. Mezrioui and B. Baleux, "Effets de la température, du pH et du rayonnement solaire sur la survie de différentes bactéries d'intérêt sanitaire dans une eau usée épurée par lagunage," Journal of Water Science, vol. 5, no. 4, pp. 573-591, 1992.

[20] T. Zhu, Z. Wang, L. M. McMullen, T. Raivio, D. J. Simpson, and M. G. Gänzle, "Contribution of the locus of heat resistance to growth and survival of Escherichia coli at alkaline $\mathrm{pH}$ and at alkaline $\mathrm{pH}$ in the presence of chlorine," Microorganisms, vol. 9, no. 4, p. 701, 2021.
[21] N. Beales, "Adaptation of microorganisms to cold temperatures, weak acid preservatives, low $\mathrm{pH}$, and osmotic stress: a review," Comprehensive Reviews in Food Science and Food Safety, vol. 3, no. 1, pp. 1-20, 2004.

[22] K. A. Presser, D. A. Ratkowsky, and T. Ross, "Modelling the growth rate of Escherichia coli as a Function of $\mathrm{pH}$ and lactic acid concentration," Applied and Environmental Microbiology, vol. 63, no. 6, pp. 2355-2360, 1997.

[23] E. A. Wahyuni, "The influence of $\mathrm{pH}$ characteristics on the occurrence of coliform bacteria in madura strait," Procedia Environmental Sciences, vol. 23, pp. 130-135, 2015.

[24] X. Chen, G. Chen, and P. L. Yue, "Separation of pollutants from restaurant wastewater by electrocoagulation," Separation Purification Technology, vol. 19, no. 1-2, pp. 65-76, 2000.

[25] S. Sloat and C. Ziel, "The use of indicator organisms to assess public water safety," pp. 1-15, HACH Technical Centre for Applied Analytical Chemistry, HACH Company, Loveland, CL, USA, 1992, Technical Information series-Booklet No.13.

[26] K. Aronsson, E. Borch, B. Stenlöf, and U. Rönner, "Growth of pulsed electric field exposed Escherichia coli in relation to inactivation and environmental factors," International Journal of Food Microbiology, vol. 93, no. 1, pp. 1-10, 2004.

[27] I. Linares-Hernández, C. Barrera-Díaz, G. Roa-Morales, B. Bilyeu, and F. Ureña-Núñez, "Influence of the anodic material on electrocoagulation performance," Chemical Engineering Journal, vol. 14, pp. 897-105, 2009.

[28] M. Y. Mollah, P. Morkovsky, J. A. Gomes, M. Kesmez, J. Parga, and D. L. Cocke, "Fundamentals, present and future perspectives of electrocoagulation," Journal of Hazardous Materials, vol. 114, no. 1-3, pp. 199-210, 2004.

[29] A. E. Yilmaz, R. Boncukcuoğlu, M. M. Kocakerim, and B. Keskinler, "The investigation of parameters affecting boron removal by electrocoagulation method," Journal of Hazardous Materials, vol. 125, no. 1-3, pp. 160-165, 2005.

[30] I. D. Tegladza, Q. Xu, K. Xu, G. Lv, and J. Lu, "Electrocoagulation processes: a general review about role of electrogenerated flocs in pollutant removal," Process Safety and Environmental Protection, vol. 146, pp. 169-189, 2021.

[31] H. J. Lu, F. Breidt, I. M. Pérez-Díaz, and J. A. Osborne, "Antimicrobial effects of weak acids on the survival of Escherichia coli O157:H7 under anaerobic conditions," Journal of Food Protection, vol. 74, no. 6, pp. 893-898, 2011.

[32] M. H. Brown and I. R. Booth, "Acidulants and low pH," in Food Preservatives, N. J. Russell and G. W. Gould, Eds., pp. 22-43, Blackie, Glasgow, Scotland, 1991.

[33] R. J. Rowbury, "Regulatory components, including integration host factor, CysB and $\mathrm{H}-\mathrm{NS}$, that influence $\mathrm{pH}$ responses in Escherichia coli," Letters in Applied Microbiology, vol. 24, no. 5, pp. 319-328, 1997.

[34] C. Delaire, C. M. van Genuchten, S. E. Amrose, and A. J. Gadgil, "Bacteria attenuation by iron electrocoagulation governed by interactions between bacterial phosphate groups and Fe(III) precipitates," Water Research, vol. 103, pp. 74-82, 2016.

[35] Y. Li, M. Wu, D. Zhao et al., "Electroporation on microchips: the harmful effects of $\mathrm{pH}$ changes and scaling down," Scientific Reports, vol. 5, no. 1, Article ID 17817, 2016.

[36] H. Vega-Mercado, U. R. Pothakamury, F. J. Chang, G. V. Barbosa-Cánovas, and B. G. Swanson, "Inactivation of E. coli by combining $\mathrm{pH}$, ionic strength and pulsed electric fields hurdles," Food Research International, vol. 29, no. 2, pp. 117-121, 1997. 
[37] P. M. Wiggins, "Cellular functions of a cell in a metastable equilibrium state," Journal of Theoretical Biology, vol. 52, no. 1, pp. 99-111, 1975.

[38] S. E. Gilliland and M. L. Speck, "Mechanism of the bactericidal action produced by electrohydraulic shock," Applied Microbiology, vol. 15, no. 5, pp. 1038-1044, 1967.

[39] D. Czajkowskal, A. Witkowska-Gwiazdowska, I. Sikorska, H. Boszczyk-Maleszak, and M. Horoch, "Survival of Escherichia Coli serotype O157:H7 in water and in bottom-shore sediments," Polish Journal of Environmental Studies, vol. 14, no. 4 , pp. 423-430, 2005.

[40] J. M. Jay, "Intrinsic and extrinsic parameters of foods that affect microbial growth," in Modern Food Microbiology, pp. 38-62, Van Nostrand Reinhold, New York, NY, USA, 4th edition, 1991.

[41] C. Delaire, C. M. Van Genuchten, K. L. Nelson, S. E. Amrose, and A. J. Gadgil, "Escherichia coli attenuation by Fe electrocoagulation in synthetic Bengal groundwater: effect of $\mathrm{pH}$ and natural organic matter," Environmental Science \& Technology, vol. 49, no. 16, pp. 9945-9953, 2015.

[42] N. Mameri, A. R. Yeddou, H. Lounici, D. Belhocine, H. Grib, and B. Bariou, "Defluoridation of septentrional Sahara water of North Africa by electrocoagulation process using bipolar aluminium electrodes," Water Research, vol. 32, no. 5, pp. 1604-1612, 1998.

[43] B. Lekhlif, L. Oudrhiri, F. Zidane, P. Drogui, and J. F. Blais, "Study of the electrocoagulation of electroplating industry wastewaters charged by nickel (II) and chromium (VI)," Journal of Materials and Environmental Science, vol. 5, no. 1, pp. 111-120, 2014.

[44] I. R. Booth, R. G. Kroll, and G. W. Gould, The Preservation of Foods by Low pH. Mechanisms of Action of Food Preservation Procedures, Elsevier Applied Science, Elsevier Science Publishers Ltd., London, UK, 1989.

[45] M. Mascia, S. Monasterio, A. Vacca, and S. Palmas, "Electrochemical treatment of water containing Microcystis aeruginosa in a fixed bed reactor with three-dimensional conductive diamond anodes Microcystis aeruginosa in a fixed bed reactor with three-dimensional conductive diamond anodes," Journal of Hazardous Materials, vol. 319, no. 5, pp. 111-120, 2016.

[46] K. L. Dubrawski and M. Mohseni, "In-situ identification of iron electrocoagulation speciation and application for natural organic matter (NOM) removal," Water Research, vol. 47, no. 14, pp. 5371-5380, 2013.

[47] J. Heffron, B. McDermid, and B. K. Mayer, "Bacteriophage inactivation as a function of ferrous iron oxidation," Environmental Science: Water Research \& Technology, vol. 5, no. 7, pp. 1309-1317, 2019.

[48] M. Birbir, H. Hacıoğlu, Y. Birbir, and G. Altuğ, "Inactivation of Escherichia coli by alternative electric current in rivers discharged into sea," Journal of Electrostatics, vol. 67, no. 4, pp. 640-645, 2009.

[49] B. M. Mackey, "Injured bacteria," in The Microbiological Safety and Quality of Foods, B. M. Lund, A. C. Baird-Parker, and G. W. Gould, Eds., pp. 315-341, Aspen Publishers, Maryland, MY, USA, 2000. 